\title{
Molecular Docking Studies of Phytochemicals from Leucas aspera Targeting Escherichia coli and Bacillus subtilis Subcellular Proteins
}

\author{
Vivek Jagadeesan Sharavanan, Muthusaravanan Sivaramakrishnan, Ram Kothandan, \\ Shanmugaprakash Muthusamy, Kumaravel Kandaswamy*
}

\section{Vivek Jagadeesan Sharavanan, Muthusara- vanan Sivaramakrishnan, Ram Kothandan, Shanmugaprakash Muthusamy, Kumaravel Kandaswamy*}

Department of Biotechnology, Laboratory of Molecular Biology and Genetic Engineering, Kumaraguru College of Technology, Coimbatore, Tamil Nadu, INDIA.

\section{Correspondence}

Dr. Kumaravel Kandaswamy

Department of Biotechnology, Laboratory of Molecular Biology and Genetic Engineering, Kumaraguru College of Technology, Coimbatore, Tamil Nadu, INDIA.

Phone no : +91-7708257489

E-mail: kumaravel.k.bt@kct.ac.in

History

- Submission Date: 15-09-2018:

- Review completed: 12-11-2018;

- Accepted Date: 12-12-2018

DOI : 10.5530/pj.2019.11.43

Article Available online

http://www.phcogj.com/v11/i2

Copyright

(C) 2019 Phcog.Net. This is an openaccess article distributed under the terms of the Creative Commons Attribution 4.0 International license.

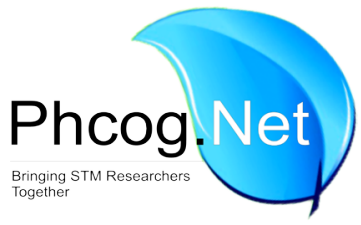

\begin{abstract}
Objective: Bacterial subcellular proteins play a vital role in cell division, pilus assembly and virulence. In addition, such proteins were perceived as potential antimicrobial targets. Therefore, in this article we attempt to screen for potential phytochemicals that can target those subcellular proteins. Methods: A computational screening for phytochemicals from Leucas aspera with better bioavailability followed by molecular docking studies for better understanding of interaction between phytochemical and target proteins. Results: erythro-2-(4-allyl-2,6dimethoxyphenoxy)-1-(4-hydroxy-3-methoxyphenyl) propan-1-ol and Leucasperone B from Leucas aspera possess great binding affinity (> $-100 \mathrm{kcal} / \mathrm{mol})$ towards one or more bacterial subcellular protein targets and possess bioavailability. Conclusion: Based on the docking result we claim that erythro-2-(4-allyl-2,6-dimethoxyphenoxy)-1-(4-hydroxy-3-methoxyphenyl) propan-1-ol and Leucasperone B could serve as an effective antimicrobial compounds to treat bacterial infections.

Key words: Docking, Phytochemicals, Antimicrobials, Subcellular proteins, Computational screening.
\end{abstract}

\section{INTRODUCTION}

Drug resistant bacterial strains pose a serious challenge to physicians as they cause numerous recurrent infections in humans. Bacteral strains such as Pseudomonas aeruginosa (P. aeruginosa), Escherichia coli (E. coli), Streptococcus Pyogenes (S. Pyogenes) gained attention for their ability to cause Cystic fibrosis, a chronic lung infection in humans. ${ }^{1}$ Urinary Tract Infections, ${ }^{2}$ Pharyngitis, respectively. ${ }^{3}$ Usage of antibiotics was one of the well-established strategy to mitigate the effects of aforementioned bacterial infections. For instance, antibiotics such as Methicillin, Penicillin, macrolides, fluoroquinolones, sulfonamides, tetracycline and aminoglycosides have been proven to inhibit bacterial cell wall synthesis thereby halting the entire cell division process. ${ }^{4}$ However, excessive usage of antibiotics resulted in emergence of drug resistant bacterial strains. ${ }^{5}$ Resistance to antibiotic (methicillin) was first demonstrated in the year 1963 using Methicillin Resistant Staphylococcus aureus (MRSA). Subsequently, studies on Antimicrobial Resistance (AMR) was conducted on S. aureus, which exhibited abnormal cell division when exposed to antimicrobial peptides. ${ }^{6}$ Furthermore, recent studies on AMR clearly shows that during the course of evolution, bacterial species can even gain resistance against antimicrobial peptides. ${ }^{7-8}$ Therefore, a novel compound has to be identified to avoid the detrimental effects to drug resistant bacterial strains. This article describes the use of virtual screening for selection of phytochemicals as a potential antimicrobial agent targeting Escherichia coli (E. coli) and Bacillus subtilis (B. subtilis) subcellular proteins. In this article, we confirm the antimicrobial nature of screened phytochemicals by Molecular docking studies. Findings from this study indicates that phytochemicals Leucosperone B, erythro-2-(4-allyl-2,6dimethoxyphenoxy)-1-(4-hydroxy-3-methoxyphenyl) propan-1-ol from Machilus odoratissima, Machilus thunbergii, Leucas aspera, Myristica fragrans and Iryanthera ulei possesses bioavailability and favourable molecular interaction with amino acids present on the active site of selected bacterial subcellular proteins.

\section{MATERIALS AND METHODS}

\section{Target selection}

Studies have demonstrated that a diverse range of molecules such as proteins, ${ }^{9-10}$ lipids $^{11-12}$ and DNA ${ }^{13}$ are organized at specific locations in and/or around bacterial cell. Such a spatial organization of molecules is crucial in controlling various bacterial developmental programs such as cell wall synthesis, cell 
division and chromosomal segregation. ${ }^{14-15}$ For example, FtsZ a cytoskeletal protein localized in a ring-like pattern at the septum of the cell is crucial for correct placement of the cell division site. ${ }^{16-17}$ DisA, a checkpoint protein, moves and scans across the cytosol to check for lesions in DNA during chromosomal replication. ${ }^{18}$ Penicillin binding protein $(\mathrm{Pbp} 2)$, which is also co-localized with FtsZ at the septum, plays a major role in cell wall synthesis during cytokinesis. Therefore, in this study we have identified bacterial subcellular proteins such as FtsZ, MreB, MreC, ParM, ZapD and Alp7A (Table 1) from various bacterial species as potential antimicrobial targets.

\section{Selection of subcellular protein targets}

MreB is a bacterial cytoskeleton protein that has been identified as an actin homologue. ${ }^{19}$ E. coli has a single MreB protein ${ }^{19}$ and they form helical cables that are responsible for the maintenance of the rod shape of E.coli. ${ }^{20}$ The membrane-associated MreB filaments coordinate bacterial cell-wall synthesis. ${ }^{21}$ The helical structures formed by the MreB are thought to be involved in the spatial organization of penicillin-binding proteins $(\mathrm{Pbps}),{ }^{20}$ which spatially coordinates the cell wall peptidoglycan synthesis.

Studies in the past infer that antibiotic resistance of bacteria can be compromised by targeting its cytoskeleton proteins such as MreB and MreC. ${ }^{22} \mathrm{MreC}$ is a cytoskeleton protein that determines the shape of a bacterial cell. Bacterial strains that does not express a functional MreC undergoes significant morphological and growth defects. ${ }^{23}$ Furthermore, $\mathrm{MreC}$ controls cell viability. ${ }^{19} \mathrm{MreC}$ forms a complex with MreB. The MreB, C and D proteins in Escherichia coli create an essential membranebound complex. ${ }^{24}$

ParM is a prokaryotic actin homologue which segregates large DNA plasmids. ParM helps the R1 plasmids (imparting multi-drug antibiotic resistance) to drive to the opposite ends of the cell before cytokinesis. ${ }^{25-26}$ Structure of ParM protein shows plasmid segregating spindles. ${ }^{27}$ ParM protein exhibits activity to that of ATPases and interacts well with the centromere like ParR- parC complex. ${ }^{28}$

ZapD protein belongs to a group of FtsZ regulatory proteins. It aids in midcell division machinery in E. coli. ${ }^{29}$ ZapD protein stabilizes FtsZ assembly and forms the $\mathrm{Z}$ ring. ${ }^{30} \mathrm{ZapD}$ protein is a small soluble protein that binds and bundles FtsZ filaments. This Z-ring assembly supports the

Table 1: Subcellular protein targets and their localization patterns in Bacillus subtilis and Escherichia coli.

\begin{tabular}{|c|c|c|c|c|}
\hline S.No & Protein & $\begin{array}{l}\text { Bacterial } \\
\text { species }\end{array}$ & Localization pattern & References \\
\hline 1 & MreB & $\begin{array}{l}\text { Bacillus subtilis } \\
\text { and Escherichia } \\
\text { coli }\end{array}$ & $\begin{array}{l}\text { Helical pattern along } \\
\text { the longitudinal axis of } \\
\text { the whole cell. }\end{array}$ & 55,56 \\
\hline 2 & MreC & $\begin{array}{l}\text { Bacillus subtilis } \\
\text { and Escherichia } \\
\text { coli }\end{array}$ & $\begin{array}{l}\text { Helical pattern along } \\
\text { the longitudinal axis of } \\
\text { the whole cell. }\end{array}$ & 57,58 \\
\hline 3 & FtsZ & $\begin{array}{l}\text { Bacillus subtilis } \\
\text { and Escherichia } \\
\text { coli }\end{array}$ & $\begin{array}{l}\text { Assembles into a ring } \\
\text { at the future site of the } \\
\text { septum of bacterial cell } \\
\text { division. }\end{array}$ & 59,60 \\
\hline 4 & ParM & $\begin{array}{l}\text { Bacillus subtilis } \\
\text { and Escherichia } \\
\text { coli }\end{array}$ & $\begin{array}{l}\text { Intaracellular filaments } \\
\text { along the length of cell }\end{array}$ & 26 \\
\hline 5 & ZapD & $\begin{array}{l}\text { Bacillus subtilis } \\
\text { and Escherichia } \\
\text { coli }\end{array}$ & $\begin{array}{c}\text { Focal localization at the } \\
\text { Mid-Cell at the Septum } \\
\text { in a FtsZ dependent } \\
\text { manner. }\end{array}$ & 61 \\
\hline
\end{tabular}

Table 2: Phytochemicals with good ADME and Drug likeness score.

\begin{tabular}{ccccccc}
\hline Ligands & $\begin{array}{c}\text { Mw } \\
(\mathbf{g} / \\
\text { mol) }\end{array}$ & $\begin{array}{c}\text { Log } p \\
(-4.0 \text { to } \\
5.6)\end{array}$ & $\begin{array}{c}\text { HBA } \\
(\leq 10)\end{array}$ & $\begin{array}{c}\text { HBD } \\
(\leq 5)\end{array}$ & $\begin{array}{c}\text { PSA } \\
(0-150) \\
\AA 2\end{array}$ & $\begin{array}{c}\text { Drug } \\
\text { likeness } \\
\text { score }\end{array}$ \\
\hline $\begin{array}{c}\text { erythro-2-(4-allyl-2,6- } \\
\text { dimethoxyphenoxy)- } \\
\begin{array}{c}\text { 1-(4-hydroxy-3- } \\
\text { methoxyphenyl) }\end{array}\end{array}$ & 374.17 & 3.85 & 6 & 2 & 62.05 & 0.9 \\
propan-1-ol & & & & & & \\
Myristargenol B & 346.18 & 4.27 & 5 & 3 & 64.01 & 0.89 \\
Machilin C & 344.16 & 4.17 & 5 & 2 & 54.34 & 0.87 \\
Nicotine alkaloid & 162.12 & 0.99 & 2 & 0 & 13.43 & 0.03 \\
Diisobutylphthalate & 278.15 & 4.41 & 4 & 0 & 42.5 & 0.07 \\
Catechin & 290.08 & 1.88 & 6 & 5 & 90.45 & 0.92 \\
Acacetin & 284.07 & 3.41 & 5 & 3 & 63.49 & 0.52 \\
Chrysoeriol & 300.06 & 3.03 & 6 & 3 & 80.13 & 0.65 \\
Apigenin & 270.05 & 3.06 & 5 & 3 & 73.57 & 0.77 \\
epi- a-bisabolol & 222.2 & 4.97 & 1 & 1 & 16.29 & 0.11 \\
Leucasperone A & 478.26 & 3.21 & 8 & 1 & 91.77 & 0.55 \\
Leucasperone B & 436.25 & 2.76 & 7 & 2 & 87.52 & 0.64 \\
\hline
\end{tabular}

formation of divisomes and aids in the overall fitness of the cell division process. ${ }^{31}$

FtsZ is a protein which is a prokaryotic homologue to the eukaryotic protein tubulin. ${ }^{32} \mathrm{FtsZ}$ is a GTPase that is essential for cell division in B. subtilis. In B. subtilis, FtsZ forms a $Z$ ring at the edge of nascent septum. ${ }^{33}$ By targeting FtsZ, cell division of a bacterial cell can be inhibited to a greater extent. ${ }^{34}$ The ring pattern of FtsZ is dependent upon SepF, which is a protein conserved in most gram-positive bacteria. This protein is required in later stage of cell division. It has a major role in septum development, hence the name SepF. ${ }^{35} \mathrm{SepF}$ forms large protein rings that also acts as a membrane anchor for Z-ring. ${ }^{36} \mathrm{SepF}$ also increases the assembly and bundling of FtsZ filaments. ${ }^{37}$

In addition to the aforementioned proteins, Alp7A an actin-like bacterial cytoskeleton protein present in bacteria such as B.subtilis. ${ }^{38}$ The main function of Alp7A is to aid plasmid segregation. Alp7A protein also exhibits tread milling and dynamic instability. ${ }^{39}$ It segregates low copy plasmid pLS20 in B.subtilis. ${ }^{40}$

\section{Retrieval and Preparation of target protein}

Either crystalized or homology modeled structures of the aforementioned biologically important membrane proteins of strains B. subtilis and E. coli were retrieved from Protein Data Bank (PDB) and Universal Protein (Uniprot) resource database and prepared using protein preparation module of MVD 4.0..$^{41-42}$ It assigns missing bonds, bond order, flexible torsions and charges to the input structures during the preparation process and makes them readily available for docking studies.

\section{Retrieval and Preparation of ligands}

Previously reported phytochemicals of Leucas aspera were listed (Table 2) and its 3-Dimensional structure was retrieved from PubChem and Chemspider databases and prepared for docking studies. Prepare molecule module of MVD 4.0 was used in this study. In MVD, during the preparation process, assigns missing charges, bonds, bond order and hybridization, detects flexible torsions, creates explicit hydrogens and finally energy-minimized structure can be obtained. Based on the structural similarity with known inhibitors 50 phytochemicals of Leucas aspera 
were selected as ligands and subjected to ADME test, Toxicity risk assessment test, Lipinski, other related Index based filters and Bioavailability.

\section{Molecular Docking}

The Molecular docking was performed to understand the inhibitory mechanism and the mode of interaction of selected phytochemicals against receptor protein. The Initial docking analysis was performed using MVD 4.0 package. The Create surface module of MVD creates double colored molecular surface according to the electrostatic property to the receptor protein. The cavity prediction algorithm predicts the cavities present in the receptor protein and display it to the user in green color and finds the potential binding sites of the receptor protein. The parameters were set to molecular surface with extended Van der Waals and number of cavities to five. The Docking was carried out using MolDock simplex evolution search algorithm with grid resolution $30 \AA$ for grid generation and cavity predicted using MVD cavity prediction algorithm. ${ }^{43}$ In cavity prediction wizard the number of cavity was restricted to three and the cavity with the large volume was selected as the origin for the binding site. The docking wizard runs with default parameters MolDock SE as a search algorithm, number of runs, maximum population and maximum iteration was limited to 10, 50 and 1500 respectively. The selected phytochemicals were docked against the receptor proteins and best-generated poses were selected based on the MVD docking scores (Figure 1). The Interaction between the ligand and the receptor protein depends on the number of $\mathrm{H}$-bonds, distance and binding energy. Some poses have favorable hydrogen bond interactions with active site amino acid residues of taget bacterial membrane proteins.

\section{Identification of potential ligands}

A virtual screening methodology was adopted to identify the potential phytochemicals capable of acting as the drug or lead compound. To identify potential ligand compounds in small time interval Index Based filters were employed. These filters eliminate the compounds with the poor lead likeness. In this study, we use five Index based filters: Lipinski filter, Goose filter, veber filter, Egan Filter and Muegge filter for eliminating poor lead like candidates. ${ }^{4}$ Those compounds pass the filters were subjected to Toxicity risk assessment test to identify whether the compound causes any adverse effect on the host system. The phytochemicals with better docking scores were subjected to ADME test using a MOLSOFT. ${ }^{41}$ It predicts ADME property of ligands based on their structure, functional groups and molecular properties i.e. Molecular Weight (M W), number of Hydrogen Bond Donors (HBD), number of Hydrogen Bond Acceptors (HBA), Polar Solvent Accessibility (PSA), Octane/water partition coefficient $(\log \mathrm{P})$. Those compounds violate expansion $(\mathrm{ADME})$ test were

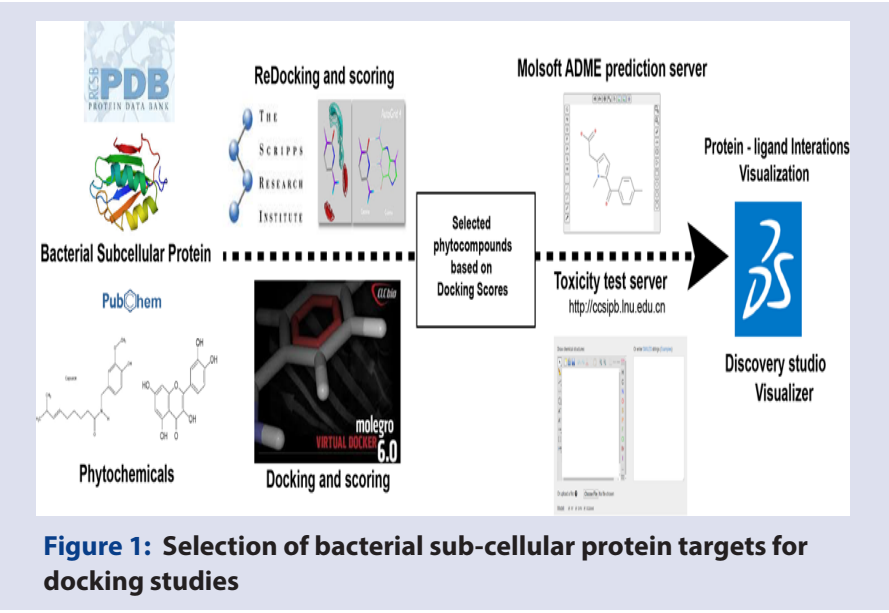

eliminated since such compounds possess poor ability to cross the biological membranes. The phytochemicals with good ADME and Drug likeness score were selected for further toxicity risk assessment tests. The toxicity risk assessment test was performed using machine learning tools Pred - Skin Web 1.0, ${ }^{45}$ Carcinopred - EL, ${ }^{46}$ hERG - Pred 4.0 (Figure 2). ${ }^{47}$

\section{Hardware and Software}

Molecular docking studies was performed on Molegro virtual Docker v 4.0. Absorption Distribution Metabolism Excretion (ADME) prediction was performed using using MOLSOFT server and Pred - Skin Web 1.0. The freeware tools Carcinopred - EL and hERG - Pred 4.0 were used for toxicity risk assessment. The workstation used in this study was equipped with AMD A8 processor with 8GB RAM and 1 TB HDD with windows 10 pro as the Operating system.

\section{RESULTS AND DISCUSSION}

In total, 50 phytochemicals from Leucas aspera have been docked against receptor protein and ligand dataset consists of 20 Terpenes/Terpenoids, 9 Sterols/fatty acids, 5 Glycosides, 7 long chain compounds, 5 flavonoids, 8 lignin and 7 miscellaneous compounds were downloaded from small molecules databases, prepared and 3D geometries were optimized. All collected phytochemicals were evaluated to identify the potential phytochemicals that has a capacity to act as a drug or lead compound. Collected ligands were then subjected to ADME test using a MOLSOFT, ${ }^{41}$ which predicts ADME property of ligands based on their structure, functional groups and molecular properties such as molecular weight (MW), number of Hydrogen Bond Donors (HBD), number of Hydrogen Bond Acceptors (HBA), Polar Solvent Accessibility (PSA), Octane/water partition coefficient $(\log \mathrm{P})$. Compounds that violate ADME test were eliminated as those compounds possess poor ability to cross the biological membranes. Only twelve ligands with good ADME and Drug likeness score were selected for further toxicity risk assessment tests and were listed in (Table 2).

The toxicity risk assessment test was performed using machine learning tools Pred - Skin Web 1.0, ${ }^{45}$ Carcinopred - EL, ${ }^{46}$ hERG - Pred 4.0. ${ }^{47}$ No ligands were identified as carcinogen, Binary prediction method of hERG - Pred predicts that ligand Nicotine alkaloid as a hERG pathway blocker. Pred - Skin predicts that only 3 ligands Leucosperone A, Leucosperone B and erythro-2-(4-allyl-2,6-dimethoxyphenoxy)-1-(4hydroxy-3-methoxyphenyl) propan-1-ol as nonsensitizers and compiled toxicity results of all selected phytochemicals were listed in Table 3.

The ligands Leucosperone B and erythro-2-(4-allyl-2,6-dimethoxyphenoxy)-1-(4-hydroxy-3-methoxyphenyl) propan-1-ol passes all five index based filters and so the selected ligands were docked against the receptor proteins and best-generated poses were selected based on the MolDock (Mdock) and Re-rank (Edock) scores. Mdock and Edock scores are scoring function used to explain the binding energy of docked poses. The Interaction between the ligand and the receptor protein depends on the number of $\mathrm{H}$-bonds, distance and binding energy. Some poses have favorable $\pi-\pi$, hydrogen bonding, van der Waals and electrostatic interactions with active site amino acid residues of bacterial membrane proteins.

During Initial stage, the phytochemicals Leucosperone B, erythro-2-(4allyl-2,6-dimethoxyphenoxy)-1-(4-hydroxy-3-methoxyphenyl) propan1-ol were docked against Escherichia coli and Bacillus subtilis subcellular proteins and their docking scores were compared with commercial antibiotics. The Commercially available antibiotic drug (penicillin) was used as controls in the study. Penicillin belongs to aminoglycosides Beta lactam antibiotic and widely used antimicrobial drug against bacterial infection. Both phytochemicals and control drug were docked against above mentioned subcellular protein receptors (as target) and only the 
Table 3: Toxicity prediction of sorted phytochemicals using machine learning tools Pred - Skin Web 1.0, Carcinopred - EL, hERG - Pred 4.0.

\begin{tabular}{|c|c|c|c|}
\hline Ligands & Carcinopred - EL & hERG - Pred 4.0 & Pred-Skin \\
\hline erythro-2-(4-allyl-2,6-dimethoxyphenoxy)-1-(4-hydroxy-3-methoxyphenyl) propan-1-ol & Non- carcinogen & Non- Blocker & Non- Sensitizer \\
\hline Myristargenol B & Non- carcinogen & Non- Blocker & Sensitizer \\
\hline Machilin C & Non- carcinogen & Non- Blocker & Sensitizer \\
\hline Nicotine alkaloid & Non- carcinogen & Blocker & Sensitizer \\
\hline Diisobutylphthalate & Non- carcinogen & Non- Blocker & Sensitizer \\
\hline Catechin & Non- carcinogen & Non- Blocker & Sensitizer \\
\hline Acacetin & Non- carcinogen & Non- Blocker & Sensitizer \\
\hline Chrysoeriol & Non- carcinogen & Non- Blocker & Sensitizer \\
\hline Apigenin & Non- carcinogen & Non- Blocker & Sensitizer \\
\hline epi- $\alpha$-bisabolol & Non- carcinogen & Non- Blocker & Sensitizer \\
\hline Leucasperone A & Non- carcinogen & Non- Blocker & Non-Sensitizer \\
\hline Leucasperone B & Non- carcinogen & Non- Blocker & Non-Sensitizer \\
\hline
\end{tabular}

Table 4: Molegro docking scores (kcal/mol) for phytochemical ligands with Escherichia coli and Bacillus subtilis subcellular protein targets.

\begin{tabular}{|c|c|c|c|c|c|c|}
\hline Compound & $\begin{array}{l}\text { Chemical } \\
\text { formula }\end{array}$ & Chemical Structure & $\begin{array}{l}\text { Protein } \\
\text { Receptors }\end{array}$ & $\begin{array}{l}\text { UNIPROT } \\
\text { entry }\end{array}$ & $\begin{array}{c}\text { MolDock } \\
\text { Score }\left(M_{\text {dock }}\right) \\
\mathrm{kJ} / \mathrm{mol}\end{array}$ & $\begin{array}{c}\text { Rerank score } \\
\left(E_{\text {dock }}\right) \\
\mathrm{kJ} / \mathrm{mol}\end{array}$ \\
\hline \multirow{7}{*}{$\begin{array}{l}\text { erythro-2-(4-allyl-2,6- } \\
\text { dimethoxyphenoxy)- } \\
\text { 1-(4-hydroxy-3- } \\
\text { methoxyphenyl) } \\
\text { propan-1-ol }\end{array}$} & \multirow{7}{*}{$\mathrm{C}_{21} \mathrm{H}_{26} \mathrm{O}_{6}$} & & MreB & P0A9X4 & -123.74 & -86.029 \\
\hline & & & MreC & P16926 & -114.98 & -76.59 \\
\hline & & & ParM & P11904 & -107.87 & -33.69 \\
\hline & & & ZapD & P36680 & -107.85 & -82.63 \\
\hline & & & Alp7A & E9RJ95 & -132.62 & -73.74 \\
\hline & & & FtsZ & P17865 & -129.1 & -107.04 \\
\hline & & & SepF & O31728 & -82.0404 & -57.454 \\
\hline \multirow{7}{*}{ Leucasperone B } & \multirow{7}{*}{$\mathrm{C}_{24} \mathrm{H}_{36} \mathrm{O}_{7}$} & & Mreb & P0A9X4 & -100.238 & -73.74 \\
\hline & & & Mrec & P16926 & -110.06 & -85.48 \\
\hline & & & ParM & P11904 & -91.7836 & -76.764 \\
\hline & & & Zapd & P36680 & -104.908 & -74.691 \\
\hline & & & Alp7A & E9RJ95 & -112.28 & -92.441 \\
\hline & & & FtsZ & P17865 & -103.16 & -70.768 \\
\hline & & & SepF & O31728 & -79.62 & -62.14 \\
\hline \multirow{6}{*}{ Penicillin } & \multirow{6}{*}{$\mathrm{C}_{16} \mathrm{H}_{18} \mathrm{~N}_{2} \mathrm{O}_{4} \mathrm{~S}$} & & MreB & P0A9X4 & -115.94 & -86.29 \\
\hline & & & MreC & P16926 & -108.64 & -87.01 \\
\hline & & & ParM & P11904 & -107.879 & -33.692 \\
\hline & & & Alp7A & E9RJ95 & -117.8 & -102.9 \\
\hline & & & FtsZ & P17865 & -119.18 & -96.96 \\
\hline & & & SepF & O31728 & -75.63 & -55.35 \\
\hline
\end{tabular}


phytochemicals with similar or better binding affinity than the control drug were selected. The Binding affinity of phytochemicals and control were evaluated using MVD 4.0 and listed in Table 4, during the docking process the cavity with larger volume was preferred as binding pocket site.

The control drug, Penicillin shows higher binding affinity against protein FtsZ with MolDock $\left(\mathrm{M}_{\text {dock }}\right)$, re rank $\left(\mathrm{E}_{\text {dock }}\right)$ score, of $-119.18 \mathrm{kcal} / \mathrm{mol}$, $-96.96 \mathrm{kcal} / \mathrm{mol}$ respectively followed by Alp7A $(-117.8 .62 \mathrm{kcal} / \mathrm{mol}$, $-102.9 \mathrm{kcal} / \mathrm{mol})$ and $\mathrm{MreB}(-115.94 \mathrm{kcal} / \mathrm{mol},-86.29 \mathrm{kcal} / \mathrm{mol})$. The penicillin with FtsZ form hydrogen bond interactions with amino acid residues such as GLY A:22, GLY A:104, GLY A:107, GLY A:110, GLY A:108, ALA:73, THR A:109, ALA A:71. penicillin form three hydrogen bonds with amino acid residues ARG A:363, SER A:13 with Alp7A. With Mreb protein, penicillin form two hydrogen bonds with amino acid residues GLY A:296, ASA A:21.

MreB shows higher binding affinity with ligands erythro2-(4-allyl-2,6dimethoxyphenoxy)-1-(4-hydroxy-3-methoxyphenyl) propan-1-ol and Leucasperone B and have MolDock score $-123.74 \mathrm{kcal} / \mathrm{mol}$ and -100.238 $\mathrm{kcal} / \mathrm{mol}$, respectively (Figure 3 ). The Lowest-energy docked poses of $\mathrm{MreC}$ with ligands erythro2-(4-allyl-2,6-dimethoxyphenoxy)-1-(4hydroxy-3-methoxyphenyl) propan-1-ol and Leucasperone B was illustrated in Figure 4.

The Leucas aspera (Willd) Linn. belongs to Family: Lamiaceae, locally known as 'Thumbai' is spread throughout India from the Himalayas down to southern Kanyakumari. Such plant species has been proven to possess various medicinal properties like antifungal, antioxidant, antimicrobial, antinociceptive and cytotoxic activity. The methanolic fraction and essential oils from Leucas aspera possess antibacterial activity against Staphylococcus aureus, Vibrio cholerae, Salmonella typhi, Klebsiella aerogenes, Escherichia coli, Proteus vulgaris, Pseudomonas pyocyaneaand Dys. Flexneri. ${ }^{48}$ Leucosperone B is a Diterpene from Leucas aspera and its proven to Inhibit Prostaglandin-Induced Contractions and NMR spectrum of the phytochemical was also available in literature ${ }^{49}$ and related databases. In this study, the Leucosperone B was docked against E. coli and B. subtilis subcellular proteins. Docking Leucosperone B with protein targets showed notable docking scores, for instance docking with $\mathrm{MreC}$ resuted in dock score, $\mathrm{M}_{\text {dock }}=-110.06 \mathrm{kcal} / \mathrm{mol}, \mathrm{E}_{\text {dock }}=-85.48 \mathrm{kcal} /$ mol. Docking with Alp7A resulted in docking score, Mdock $=-112.28$

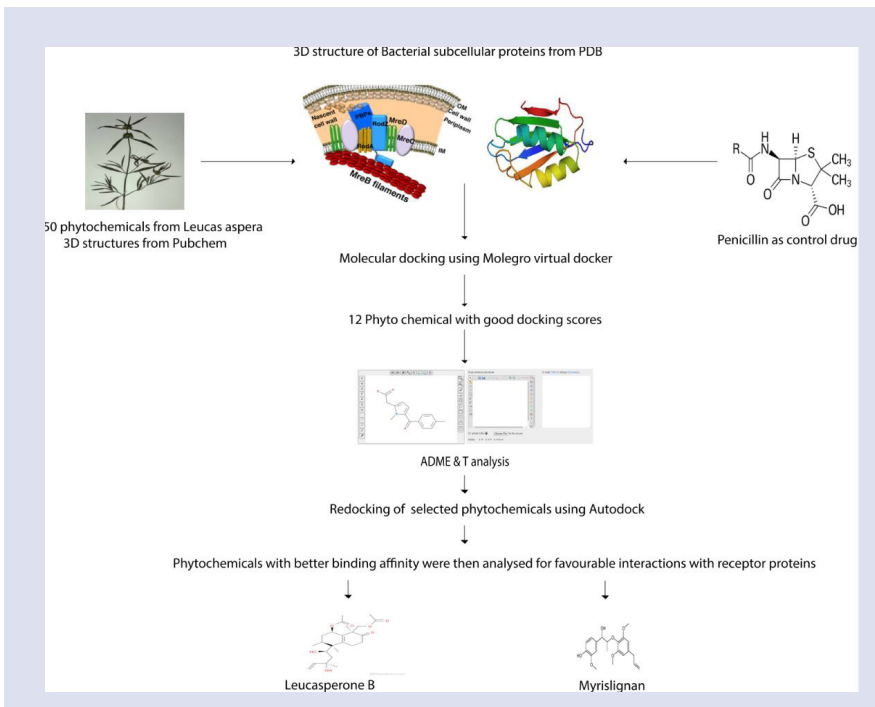

Figure 2: Flowchart explaining the target selection and docking procedure.

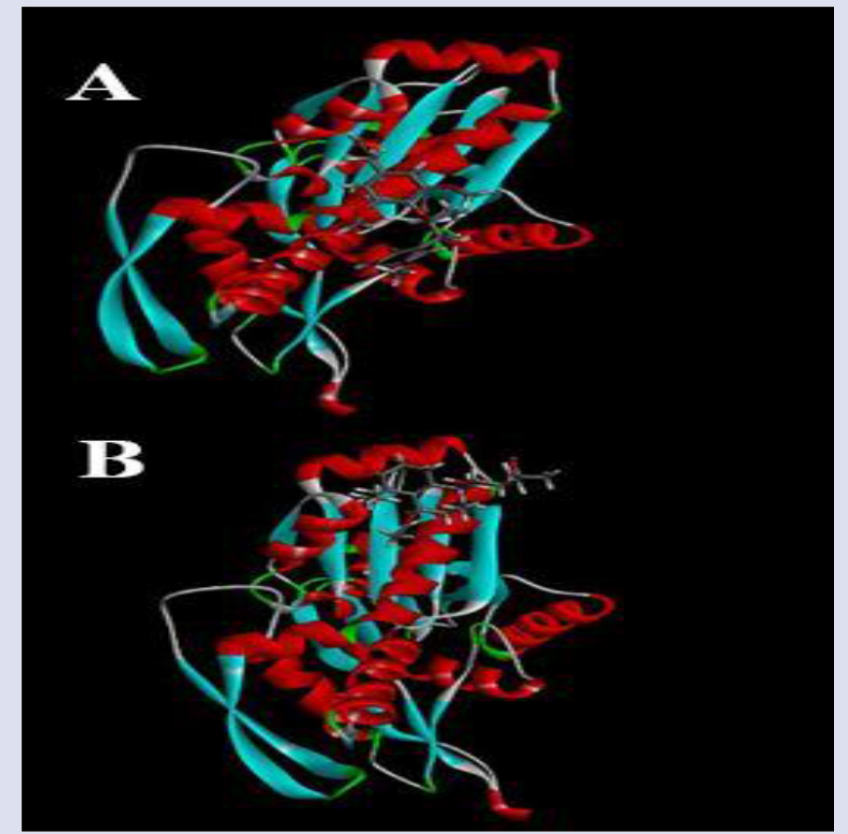

Figure 3: Lowest-energy docked poses of MreB with A) erythro2-(4-allyl-2,6-dimethoxyphenoxy)-1-(4-hydroxy-3-methoxyphenyl) propan-1-ol and B) Leucasperone B.

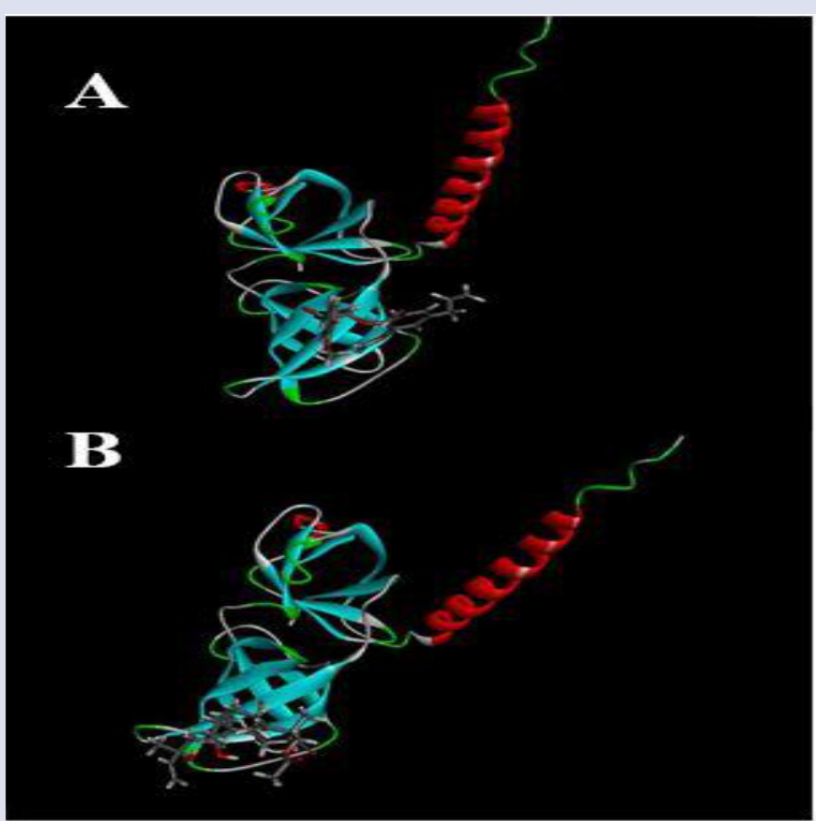

Figure 4: Lowest-energy docked poses of $\mathrm{MreC}$ with $\mathrm{A}$ ) erythro2-(4-allyl-2,6-dimethoxyphenoxy)-1-(4-hydroxy-3-methoxyphenyl) propan-1-ol and B) Leucasperone B. 


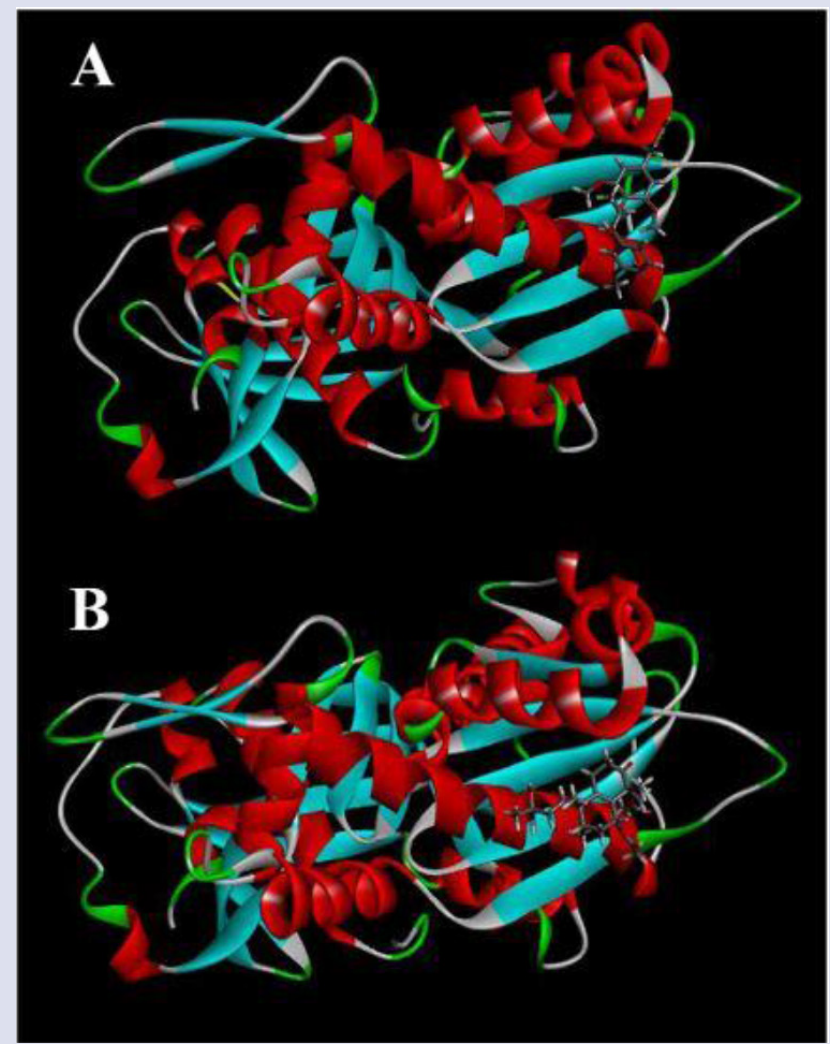

Figure 5: Lowest-energy docked poses of Alp7A with A) erythro2-(4-allyl-2,6-dimethoxyphenoxy)-1-(4-hydroxy-3-methoxyphenyl) propan-1-ol and B) Leucasperone B.

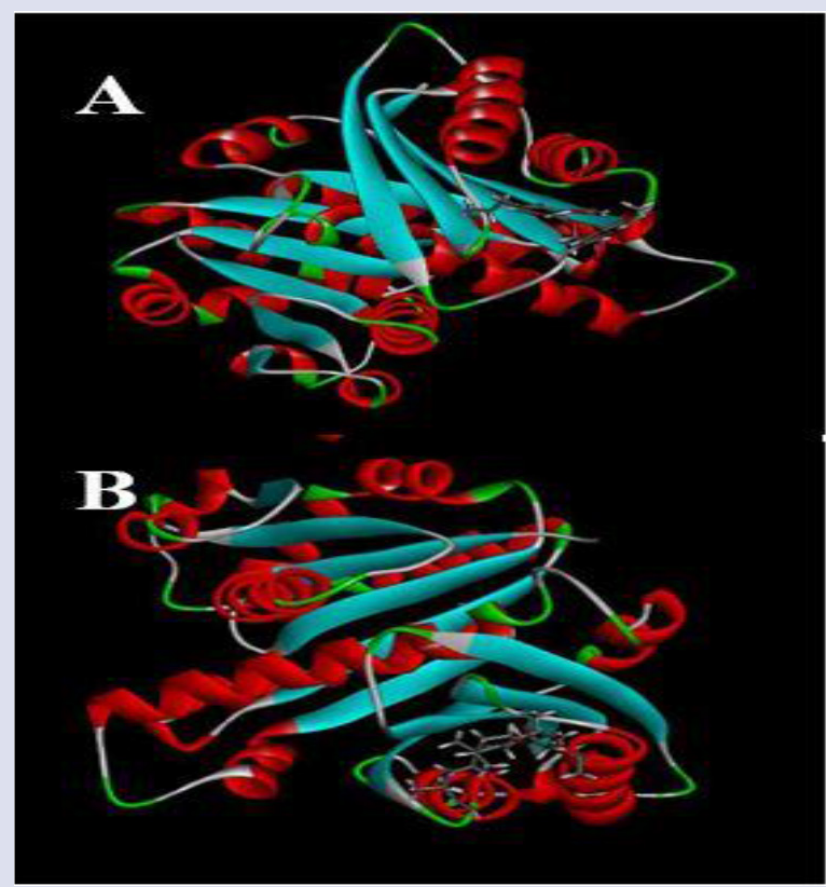

Figure 6: Lowest-energy docked poses of FtsZ with A) erythro2-(4-allyl-2,6-dimethoxyphenoxy)-1-(4-hydroxy-3-methoxyphenyl) propan-1-ol and B) Leucasperone B. $\mathrm{kcal} / \mathrm{mol}, \mathrm{E}_{\mathrm{dock}}=-92.441$. Furthermore, Leucosperone B also forms four hydrogen bonds within active site of protein MreC with amino acid residues SER A:153, GLY A:259, TYR A:265, ARG A:103 (Figure 4).

erythro-2-(4-allyl-2,6-dimethoxyphenoxy)-1-(4-hydroxy-3-methoxyphenyl) propan-1-ol is a neolignan found in plant varieties such as Machilus odoratissima, ${ }^{50}$ Machilus thunbergii, ${ }^{51}$ Leucas aspera, ${ }^{52}$ Myristica fragrans $^{53}$ and Iryanthera ulei. ${ }^{54}$ The aforementioned neolignan also showed notable docking profile with protein targets $\mathrm{MreC}\left(\mathrm{M}_{\text {dock }}=\right.$ $\left.-110.06 \mathrm{kcal} / \mathrm{mol}, \mathrm{E}_{\text {dock }}=-85.48 \mathrm{kcal} / \mathrm{mol}\right)$, Alp7A $\left(\mathrm{M}_{\text {dock }}=-112.28 \mathrm{kcal} /\right.$ $\left.\mathrm{mol}, \mathrm{E}_{\text {dock }}=-92.441\right)$. In addition, it forms four hydrogen bonds within active site of protein $\mathrm{MreC}$ and interacting amino acid residues are SER A:153, GLY A:259, TYR A:265, ARG A:103. erythro-2-(4-allyl2,6-dimethoxyphenoxy)-1-(4-hydroxy-3-methoxyphenyl) propan-1-ol when docked to the protein Alp7A at the predicted binding cavity (Figure 5), formed three hydrogen bonds with amino acid residues GLY A:215, GLY A:330, SER A:13.

\section{CONCLUSION}

In summary, in-silico screening of Leucas aspera phytochemicals was performed to identify potential phytochemicals with drug-likeness. We found that phytochemicals erythro-2-(4-allyl-2,6-dimethoxyphenoxy)1-(4-hydroxy-3-methoxyphenyl) propan-1-ol and Leucasperone B from Leucas aspera possess great binding affinity $(>-100 \mathrm{kcal} / \mathrm{mol})$ towards one or more bacterial subcellular protein targets. Both compounds possess favorable interactions with amino acid residues present in the active site pocket of bacterial cell division and cell shape determining proteins such as Mreb, Mrec, Ftsz and Alp7A have valid docking scores $(>-100 \mathrm{kcal} / \mathrm{mol}$ ) Figures (3-6). The sorted phytochemicals were found in common medicinal plants. For example, erythro-2-(4-allyl-2,6dimethoxyphenoxy)-1-(4-hydroxy-3-methoxyphenyl) propan-1-ol is a neolignan found in plant varieties such as Machilus odoratissima, ${ }^{50}$ Machilus thunbergii, ${ }^{51}$ Leucas aspera, ${ }^{52}$ Myristica fragrans $^{53}$ and Iryanthera ulei. ${ }^{54}$ However, Leucasperone B is found only in Leucas aspera sp. We believe that this work will shed light on antibacterial screening and extraction of phytochemicals from Leucas aspera. The future studies involves designing of potential structural analogs of identified compounds, chemical synthesis and to evaluate its antibacterial activity invitro.

\section{ACKNOWLEDGEMENT}

The authors gratefully acknowledge Department of Biotechnology, Kumaraguru College of Technology (KCT), Coimbatore, Tamil Nadu, India for providing us the research facilities.

\section{CONFLICT OF INTEREST}

The authors declare no conflict of interest.

\section{ABBREVIATIONS}

ADMET: Adsorption, Distribution, Metabolism, Excretion and Toxicity; MVD: Molegro Virtual Docker; Mw: Molecular weight; HBD: Hydrogen Bond Donors; HBA: Hydrogen Bond Acceptors; PSA: Polar Surface Area.

\section{REFERENCES}

1. Davies JC. Pseudomonas aeruginosa in cystic fibrosis: pathogenesis and persistence. Paediatric Respiratory Reviews. 2002;3(2):128-34

2. Flores-Mireles AL, Walker JN, Caparon M, Hultgren SJ. Urinary tract infections: epidemiology, mechanisms of infection and treatment options. Nature Reviews Microbiology. 2015;13(5):269-84. doi:10.1038/nrmicro3432

3. Anjos LM, Marcondes MB, Lima MF, Mondelli AL, Okoshi MP. Streptococca acute pharyngitis. Revista Da Sociedade Brasileira De Medicina Tropical. 
2014;47(4):409-13

4. Benveniste R, Davies J. Mechanisms of antibiotic resistance in bacteria. Annual Review of Biochemistry. 1973;42(1):471-506.

5. Levy SB. The challenge of antibiotic resistance. Scientific American. 1998;278(3):32-9.

6. Ganz T. Defensins: antimicrobial peptides of innate immunity. Nature Reviews Immunology. 2003;3(9):710-20.

7. Kandaswamy K, et al. Focal targeting by human beta-defensin 2 disrupts localized virulence factor assembly sites in Enterococcus faecalis. Proc Natl Acad Sci USA. 2013;110(50):20230-5. doi:10.1073/pnas.1319066110

8. Peters BM, Shirtliff ME, Jabra-Rizk MA. Antimicrobial peptides: primeval molecules or future drugs?. Plos Pathogens. 2010;6(10):e1001067.

9. Ellmark $P$, et al. Identification of protein expression signatures associated with Helicobacter pylori infection and gastric adenocarcinoma using recombinant antibody microarrays. Molecular and Cellular Proteomics. 2006;5(9):1638-46.

10. Carlsson $F$, et al. Signal sequence directs localized secretion of bacterial surface proteins. Nature. 2006;442(7105):943-6. doi:10.1038/nature05021

11. Rosch JW, Caparon MG. The ExPortal: an organelle dedicated to the biogenesis of secreted proteins in Streptococcus pyogenes. Molecular Microbiology. 2005;58(4):959-68. doi:10.1111/j.1365-2958.2005.04887.x

12. Rosch JW, Hsu FF, Caparon MG. Anionic lipids enriched at the ExPortal of Streptococcus pyogenes. Journal of Bacteriology. 2007;189(3):801-6. doi:10.1128/jb.01549-06

13. Berlatzky IA, Rouvinski A, Ben-Yehuda S. Spatial organization of a replicating bacterial chromosome. Proceedings of the National Academy of Sciences. 2008;105(37):14136-40.

14. Laloux G, Jacobs-Wagner C. How do bacteria localize proteins to the cell pole? Journal of Cell Science. 2014;127:11-9. doi:10.1242/jcs.138628

15. Rudner DZ, Losick R. Protein subcellular localization in bacteria. Cold Spring Harbor Perspectives in Biology. 2010;2:a000307. doi:10.1101/cshperspect. a000307

16. Strauss MP, et al. 3D-SIM super resolution microscopy reveals a bead-like arrangement for FtsZ and the division machinery: implications for triggering cytokinesis. Plos Biology. 2012;10(9):e1001389. doi:10.1371/journal.pbio.1001389

17. Rothfield L, Taghbalout A, Shih YL. Spatial control of bacterial division-site placement. Nature Reviews Microbiology. 2005;3(12):959-68. doi:10.1038/ nrmicro1290

18. Bejerano-Sagie $M$, et al. A checkpoint protein that scans the chromosome for damage at the start of sporulation in Bacillus subtilis. Cell. 2006;125(4):679-90. doi:10.1016/j.cell.2006.03.039

19. Shih YL, Rothfield L. The Bacterial Cytoskeleton. Microbiology and Molecular Biology Reviews. 2006;70(3):729-54. doi:10.1128/mmbr.00017-06

20. Divakaruni AV, Loo RR, Xie Y, Loo JA, Gober JW. The cell-shape protein MreC interacts with extracytoplasmic proteins including cell wall assembly complexes in Caulobacter crescentus. Proc Natl Acad Sci USA. 2005;102(51):18602-7. doi:10.1073/pnas.0507937102

21. Strahl H, Burmann F, Hamoen LW. The actin homologue MreB organizes the bacterial cell membrane. Nat Commun. 2014;5:3442. doi:10.1038/ncomms4442

22. Wang $H$, Xie L, Luo $H$, Xie J. Bacterial cytoskeleton and implications for new antibiotic targets. J Drug Target. 2016;24(5):392-8. doi:10.3109/106118 6X.2015.1095195

23. Tavares AC, Fernandes PB, Carballido-Lopez R, Pinho MG. MreC and MreD Proteins are not Required for Growth of Staphylococcus aureus. Plos One. 2015;10(10):e0140523. doi:10.1371/journal.pone.0140523

24. Kruse T, Bork-Jensen J, Gerdes K. The morphogenetic MreBCD proteins of Escherichia coli form an essential membrane-bound complex. Mol Microbiol. 2005;55(1):78-89. doi:10.1111/j.1365-2958.2004.04367.x

25. Gunning PW, Ghoshdastider U, Whitaker S, Popp D, Robinson RC. The evolution of compositionally and functionally distinct actin filaments. J Cell Sci. 2015;128(11):2009-19. doi:10.1242/jcs.165563

26. Moller-Jensen J, Jensen RB, Lowe J, Gerdes K. Prokaryotic DNA segregation by an actin-like filament. The EMBO Journal. 2002;21(12):3119-27. doi:10.1093/ emboj/cdf320

27. Bharat TA, Murshudov GN, Sachse C, Lowe J. Structures of actin-like ParM filaments show architecture of plasmid-segregating spindles. Nature. 2015;523(7558):106-10. doi:10.1038/nature14356

28. Jensen RB, Gerdes K. Partitioning of plasmid R1. The ParM protein exhibits ATPase activity and interacts with the centromere-like ParR-parC complex. Journal of Molecular Biology. 1997;269(4):505-13.

29. Durand-Heredia J, Rivkin E, Fan G, Morales J, Janakiraman A. Identification of ZapD as a cell division factor that promotes the assembly of FtsZ in Escherichia coli. J Bacteriol. 2012;194:3189-98. doi:10.1128/JB.00176-12

30. Schumacher MA, Huang KH, Zeng W, Janakiraman A. Structure of the Z Ringassociated Protein, ZapD, Bound to the C-terminal Domain of the Tubulin-like Protein, FtsZ, Suggests Mechanism of Z Ring Stabilization through FtsZ Crosslinking. J Biol Chem. 2017;292:3740-50. doi:10.1074/jbc.M116.773192

31. Roach EJ, et al. Structure and Mutational Analyses of Escherichia coli ZapD Reveal Charged Residues Involved in FtsZ Filament Bundling. J Bacteriol.
2016;198:1683-93. doi:10.1128/JB.00969-15

32. Erickson HP. FtsZ, a prokaryotic homolog of tubulin?. Cell. 1995;80(3):367-70.

33. Wang X, Lutkenhaus J. The FtsZ protein of Bacillus subtilis is localized the division site and has GTPase activity that is dependent upon FtsZ concentration. Molecular Microbiology. 1993;9(3):435-42.

34. Mukherjee A, Lutkenhaus J. Dynamic assembly of FtsZ regulated by GTP hydrolysis. The EMBO Journal. 1998;17(2):462-9.

35. Hamoen LW, Meile JC, De Jong W, Noirot P, Errington J. SepF, a novel FtsZinteracting protein required for a late step in cell division. Molecular Microbiology. 2006;59(3):989-99.

36. Duman $R$, et al. Structural and genetic analyses reveal the protein SepF as a new membrane anchor for the $\mathbf{Z}$ ring. Proceedings of the National Academy of Sciences. 2013;110(48):E4601-10.

37. Singh JK, Makde RD, Kumar V, Panda D. SepF increases the assembly and bundling of FtsZ polymers and stabilizes FtsZ protofilaments by binding along its length. Journal of Biological Chemistry. 2008;283(45):31116-24

38. Derman Al, et al. Alp7R regulates expression of the actin-like protein Alp7A in Bacillus subtilis. J Bacteriol. 2012;194:2715-24. doi:10.1128/JB.06550-11

39. Derman Al, et al. Phylogenetic analysis identifies many uncharacterized actinlike proteins (Alps) in bacteria: regulated polymerization, dynamic instability and treadmilling in Alp7A. Mol Microbiol. 2009;73(4):534-52. doi:10.1111/j.13652958.2009.06771.x

40. Petek NA, Derman Al, Royal JA, Pogliano J, Mullins D. Polymer dynamics of Alp7A reveals two' critical' concentrations that govern dynamically unstable actin-like proteins. Bio Rxiv. 2017;098954.

41. MolSoft I. 2.8 Program Manual. San Diego, CA: Mol Soft LLC. 2000

42. Ratnavali $G$, et al. An attempt to screen top colorectal cancer drugs by using Molegro Virtual Docker. Ann Biol Res. 2011;2:114-26.

43. Wallace AC, Laskowski RA, Thornton JM. LIGPLOT: a program to generate schematic diagrams of protein-ligand interactions. Protein Engineering, Design and Selection. 1995;8(2):127-34

44. Lipinski CA. Lead-and drug-like compounds: the rule-of-five revolution. Drug Discovery Today: Technologies. 2004;1(4):337-41.

45. Braga RC, et al. Pred-Skin: A Fast and Reliable Web Application to Assess Skin Sensitization Effect of Chemicals. Journal of Chemical Information and Modeling. 2017;57(5):1013-7.

46. Zhang L, et al. CarcinoPred-EL: Novel models for predicting the carcinogenicity of chemicals using molecular fingerprints and ensemble learning methods. Scientific Reports. 2017;7(1):2118.

47. Braga RC, et al. Pred-hERG: A Novel web-Accessible Computational Tool for Predicting Cardiac Toxicity. Molecular Informatics. 2015;34(10):698-701.

48. Rao B, Narasimha G. Antimicrobial action of some essential oils. IV. Effect of Organic Compounds. Riechstoffe, Aromen, Koerperpflegemittel. 1971;21:10-2.

49. Sadhu SK, Okuyama E, Fujimoto $H$, Ishibashi M. Diterpenes from Leucas aspera inhibiting prostaglandin-induced contractions. Journal of Natural Products. 2006;69(7):988-94. doi:10.1021/np058118m

50. Phan MG, Phan TS, Matsunami K, Otsuka H. New Neolignans and Lignans from Vietnamese Medicinal Plant Machilus odoratissima N EES. Chemical and Pharmaceutical Bulletin. 2006;54(3):380-3.

51. Shimomura H, Sashida Y, Oohara M. Lignans from Machilus thunbergii. Phytochemistry. 1987;26(5):1513-15.

52. Sadhu SK, Okuyama E, Fujimoto H, Ishibashi M. Separation of Leucas aspera, a medicinal plant of Bangladesh, guided by prostaglandin inhibitory and antioxidant activities. Chemical and Pharmaceutical Bulletin. 2003;51(5):595-8.

53. Hada S, Hattori M, Tezuka Y, Kikuchi T, Namba T. New neolignans and lignans from the aril of Myristica fragrans. Phytochemistry. 1988;27(2):563-8.

54. Bernal FA, Cuca S. Chemical constituents from Iryanthera ulei Warb. Biochemical Systematics and Ecology. 2009;37(6):772-5

55. Boeneman K, Fossum S, Yang Y, Fingland N, Skarstad K, Crooke E. Escherichia coli DnaA forms helical structures along the longitudinal cell axis distinct from MreB filaments. Molecular Microbiology. 2009;72(3):645-57.

56. Domínguez-Cuevas P, Porcelli I, Daniel RA, Errington J. Differentiated roles for MreB-actin isologues and autolytic enzymes in Bacillus subtilis morphogenesis. Molecular Microbiology. 2013;89(6):1084-98.

57. Leaver M, Errington J. Roles for MreC and MreD proteins in helical growth of the cylindrical cell wall in Bacillus subtilis. Molecular Microbiology. 2005;57(5):1196-209.

58. Okada Y, Wachi M, Hirata A, Suzuki K, Nagai K, Matsuhashi M. Cytoplasmic axial filaments in Escherichia coli cells: possible function in the mechanism of chromosome segregation and cell division. Journal of Bacteriology. 1994;176(3):917-22.

59. Beall B, Lutkenhaus J. FtsZ in Bacillus subtilis is required for vegetative septation and for asymmetric septation during sporulation. Genes and development. $1991 ; 5(3): 447-55$

60. Bi E, Lutkenhaus J. FtsZ ring structure associated with division in Escherichia coli. Nature. 1991;354(6349):161.

61. Durand-Heredia J, Rivkin E, Fan G, Morales J, Janakiraman A. Identification of ZapD as a Cell Division Factor That Promotes the Assembly of FtsZ in Escherichia coli. Journal of Bacteriology. 2012;194(12):3189-98. 
GRAPHICAL ABSTRACT

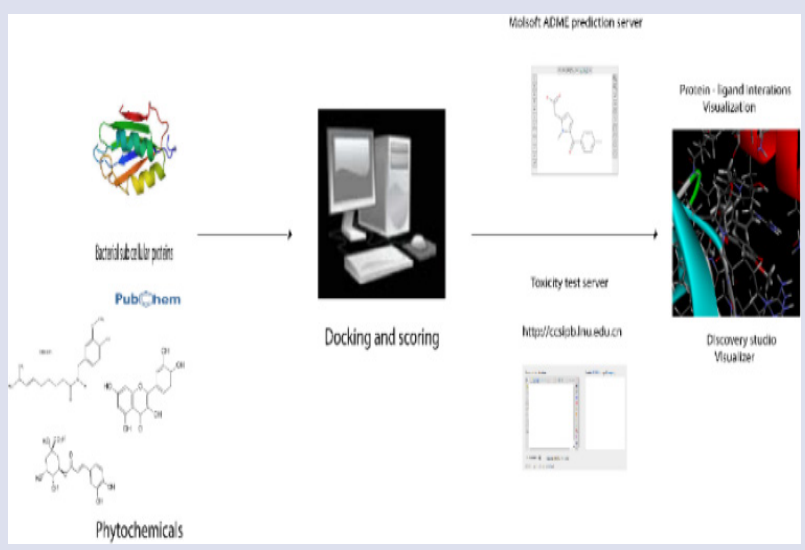

SUMMARY

- Virtual screening and ADMET studies was performed to screening phytochemicals with drug likeness from Leucas aspera.

- Molecular docking studies of screened phytochemicals against $E$ coli and B subtilis subcellular protein was performed using Molegro virtual docker.

- The docking results showed that phytochemicals Leucosperone B, erythro-2-(4 allyl-2,6-dimethoxyphenoxy)-1-(4-hydroxy-3-methoxyphenyl) propan-1-ol have good inhibition against MreB, MreC, Alp7A proteins.

- We believe that this work will shed light on antibacterial screening and extraction of phytochemicals from Leucas aspera.

\section{ABOUT AUTHORS}

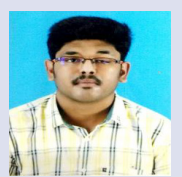

Vivek Jagadeesan Sharavanan is a final year student pursuing B.tech - Biotechnology at Kumaraguru College of Technology. His research interest is on the computational biology and recombinant DNA technology.

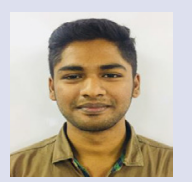

Muthusaravanan Sivaramakrishnan is a final year student pursuing B. Tech Biotechnology at Kumaraguru college of technology, Coimbatore, Tamil Nadu. His research focuses primarily on Nature-Inspired Optimization strategies, Development of modified biomaterials for Bioremediation and Antimicrobial applications.

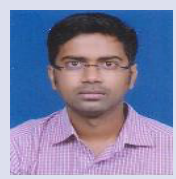

Ram Kothandan is an Assistant Professor at the Department of Biotechnology, Kumaraguru College of Technology. He received his Ph.D. in computational Biology from BITS-Pilani. His research interest is non-coding RNAs and Machine learning approach for biological problem s. Having 5 years of teaching experience and 4.7 years of research experience and hands on experience in handling a large volume of protein and nucleotide sequence.

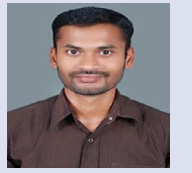

Shanmugaprakash Muthusamy is working as an Associate Professor at the Department of Biotechnology, Kumaraguru College of Technology, Coimbatore. Tamil Nadu. His research focuses mainly on product development from natural resources and Biorefinery. For his credit, he has more than 20 Papers and 1 patent granted. He has received an young scientist award from Department of Science and Technology (DST), India.

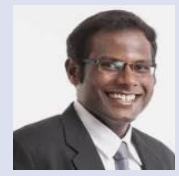

Kumaravel Kandaswamy is an Assistant Professor at the Department of Biotechnology, Kumaraguru College of Technology. He received his PhD in Molecular Microbiology and Biophysics from Nanyang Technological University (NTU, Singapore). His research focuses primarily on developing novel antimicrobial compounds to combat against microbial infections. He is a co-recipient of Foldscope grant (BT/IN/INDO-US/Foldscope/39/2015) awarded by Department of Biotechnology, Ministry of Science and Technology, Government of India.

Cite this article: Sharavanan VJ, Sivaramakrishnan M, Kothandan R, Muthusamy S, Kandaswamy K. Molecular Docking Studies of Phytochemicals from Leucas aspera Targeting Escherichia coli and Bacillus subtilis Subcellular Proteins. Pharmacog J. 2019;11(2):27885. 